\title{
重複下大静脈を伴う症例に対する腹腔鏡下傍大動脈リンパ節摘出術
}

\author{
三重県立総合医療センター 㦃婦人科 ${ }^{1}$ 、三重大学 産科婦人科 ${ }^{2)}$ \\ 小田日東美 ${ }^{1)}$ 、田中浩彦 ${ }^{1)}$ 、脇坂太貴 ${ }^{1)}$ 、秋山 登 $^{11}$ 、中野讓子 ${ }^{1)}$ 、 \\ 井澤美穂 ${ }^{1)}$ 、真川祥一 ${ }^{2)}$ 、近藤英司 ${ }^{2)}$
}

\section{Laparoscopic para-aortic lymphadenectomy in patients with a double inferior vena cava

\author{
Hitomi Oda ${ }^{1)}$,Hirohiko Tanaka ${ }^{1)}$,Hiroki Wakisaka ${ }^{1)}$, Noboru Akiyama $^{1)}$, \\ Masako Nakano ${ }^{1)}$,Miho Izawa ${ }^{1)}$,Shoichi Magawa ${ }^{2)}$,Eiji Kondo ${ }^{2)}$ \\ Mie Prefectural General Medical Center ${ }^{1)}$, \\ Department of Obstetrics and Gynecology, Mie University Hospital ${ }^{2)}$
}

\begin{abstract}
Objective: Double inferior vena cava is a congenital venous anomaly with an incidence of $1-3 \%$. Several patients with anomalies of the great vessels present with complications such as minor anomalies of blood vessels. A thorough understanding of the positional relationships and anatomical construction is essential to perform safe and effective surgery. At our hospital, as a matter of policy, preoperative three-dimensional computed tomography (3D-CT) is performed in all patients undergoing laparoscopic para-aortic lymphadenectomy (PAN) to confirm the presence of anomalies of the great vessels. We report PAN performed in 2 patients with a double inferior vena cava.

Both patients presented with early ovarian cancer, and staging surgery including PAN was performed. The double inferior vena cava was identified on preoperative 3D-CT. Transperitoneal PAN was performed in both patients. No other concomitant anomaly was observed. Although a careful operation was required with regard to several points, no massive bleeding necessitating blood transfusion or complications occurred, and surgery could be safely performed.

Conclusion: A transperitoneal approach provides better intraoperative orientation than a retroperitoneal approach, because with this approach, the left inferior vena cava is unlikely to interfere with the operation. Therefore, preoperative 3D-CT may be useful to select the optimal approach for PAN.
\end{abstract}

Key words: laparoscopic para-aortic lymphadenectomy, transperitoneal, anomalies of the inferior vena cava

\section{緒言}

腹腔鏡下手術で認められた傍大動脈リンパ節領 域における脈管anomalyは30.2\%にも上るという 報告があり ${ }^{1)}$ 、婦人科悪性腫瘍に対する腹腔鏡手 術において血管anomaly合併症例に遭遇する可能 性は低くない。当科では腹腔鏡下傍大動脈リンパ 節摘出術 (para-aortic lymphadenectomy、以下 PAN手術）を行う際、原則術前に3D-CT画像検 査を行い、大血管anomalyの有無を確認している。
今回、重複下大静脈を伴った症例に対LPAN手 術を行う機会が 2 例あった。

なお、一般的に解剖学領域において、形態的原 則から逸脱し、かつ機能的問題を生じない場合、 その形態異常を破格と呼び、機能障害をもたらす 場合を奇形と呼ぶ。しかし本稿では混乱を避ける ために、機能異常の有無に関わらず、先天的構造 異常をanomalyと呼称することに統一した。 


\section{症 例 (1)}

38 歳、 1 妊 0 産、特記すべき既往歴はなかった。 挙児希望にて近医を受診した際に、両側付属器腫 大を指摘され、精査加療目的に当科紹介となった。 MRI検査にて右卵巣に径 $10 \mathrm{~cm}$ 、左卵巣に径 $6 \mathrm{~cm}$ の子宮内膜症性囊胞を認め、右側囊胞には一部弱 く造影される充実性領域を認めた。CT検査によ るリンパ節腫大や転移所見は認めなかった。卵巣 癌を疑ったが、強い挙児希望のためまずは腹式右 付属器切除術を施行し、永久病理標本にて組織の 確認を行う方針とした。腹腔内に播種を疑う所見 はなく、腹水貯留も認めなかった。術中被膜破綻 があり、術後病理検査では類内膜癌G3、被膜浸 潤なく、脈管侵襲もなかった。

本人は挙児を断念し、基本術式およびstaging 手術を施行することとなった。追加手術は回復が 早く、術後化学療法導入までの期間が短い利点な どを考慮し、腹腔鏡下手術を予定した。当科では 平成 24 年 8 月に早期卵巣癌に対するlaparoscopic surgical staging実施について当院倫理委員会の 承認を得ている（倫理委員会承認番号 第201724 号)。本人、家族にインフォームドコンセント を行い書面にて同意を得た。術前3D-CT検査（図 1 ）では、本来の下大静脈とは別に大動脈左側に も下大静脈に相当する大血管を認め、重複下大静 脈を疑った。腹腔鏡下にて子宮全摘術、左付属器 切除術、大網切除術を施行した。未産婦のため小 切開を下腹部に加え、子宮、左付属器、大網は経 腹的に搬出した。続いて経腹膜的アプローチによ

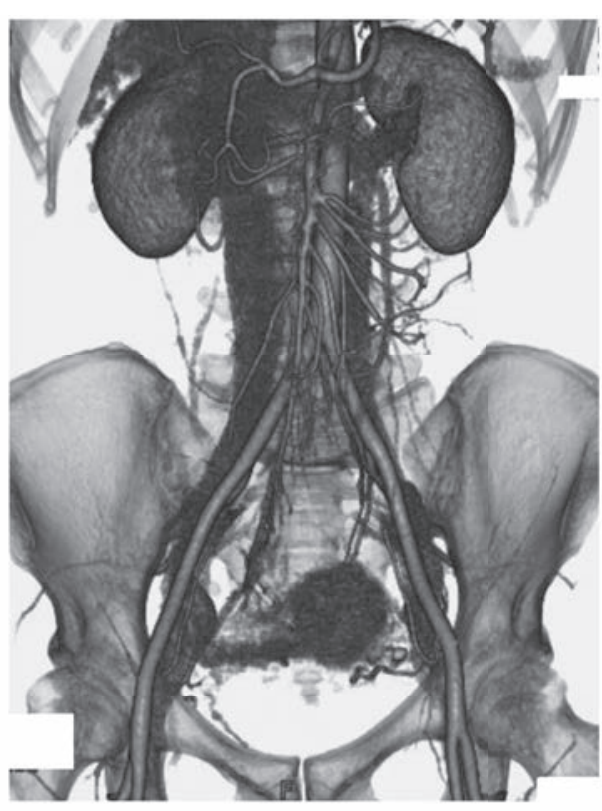

図 1 症例 13 3D-CT画像。本来の下大静脈とは別 に大動脈左側に左下大静脈を認める。仙骨前面 に左総腸骨静脈を確認できない。

るPAN手術を含めたstaging手術を施行した。

手術法と手術所見：約 10 度の骨盤高位とし、臍部 $12 \mathrm{~mm}$ ポート 1 点、左右および正中下腹部 $5 \mathrm{~mm}$ ポート 3 点、臍より $5 \mathrm{~cm}$ 離れた右上腹部に 5 $\mathrm{mm}$ 、左上腹部に $12 \mathrm{~mm}$ ポートを設置した。

子宮全摘術、左付属器切除術、大網切除術拧よ び骨盤リンパ節切除術を定型通り施行し、その後 PAN手術を行った。

PAN摘出術野展開時、術者・助手は図 2 のよ うに配置した。まず、術者は(3)、助手は(1)と(2)の 位置で、カメラは下腹部中央 $5 \mathrm{~mm}$ ポートより直

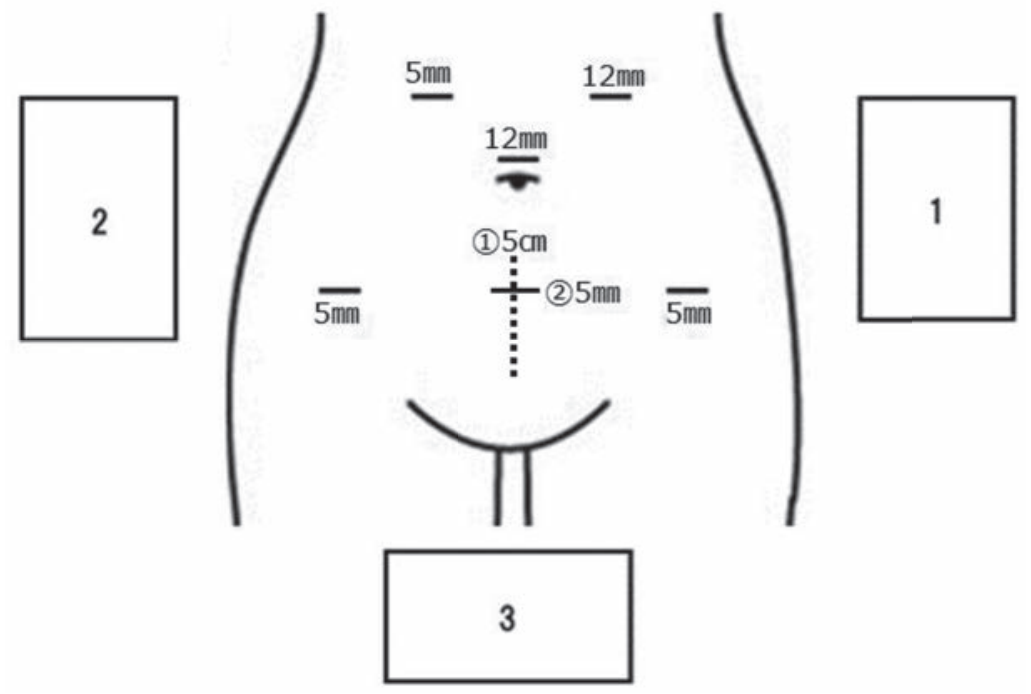

図2 ポート・人員の配置。症例 1 と症例 2 の下腹部切開創をそれぞれ点線(1)と実線(2)で 表した。症例 1 では $5 \mathrm{~cm}$ へ切開創を延長した。 
視鏡を挿入し患者頭側を見上げる視野で開始し た。腹膜切開を行い、大動脈右側のリンパ節を摘 出した。大動脈左側のリンパ節、いわゆるleft lateral chainの摘出と下腸間膜動脈 (以下IMA) 根部の露出を行っている段階で、左側下大静脈を 同定した（写真 1)。Left lateral chainは一旦、 低位傍大動脈リンパ節 (以下B2) の途中で切断し、 摘出を頭側へ進め、IMAの下をくぐらせ、頭側 に出した。操作中は左下大静脈が接近していたた め (写真 2$)$ 、損傷を避け、さらに異常血管がな

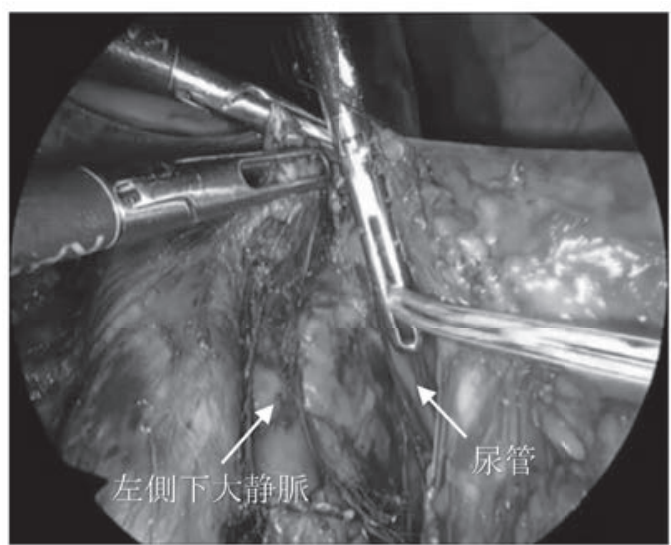

写真 1 大動脈左側に左側下大静脈を同定した。写真上が頭側。

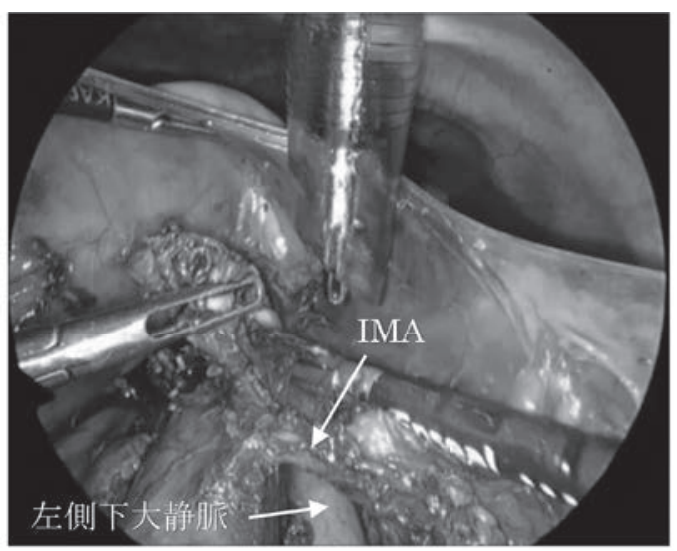

写真2 IMA周囲の操作では左下大静脈が近接していた。写真上が頭側。

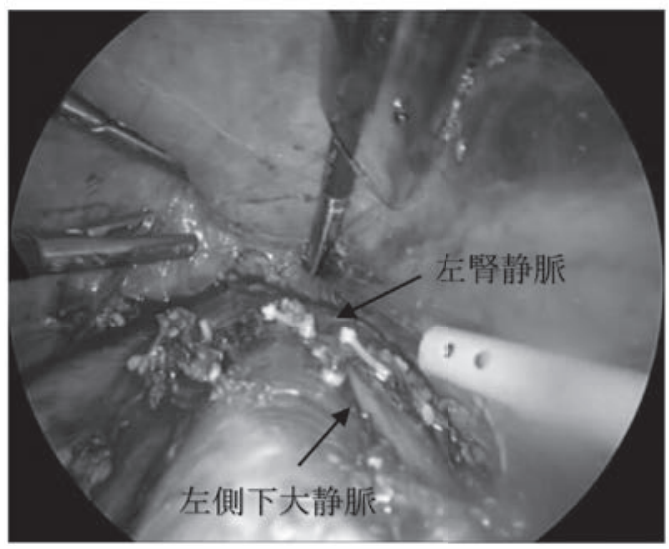

写真 3 左側下大静脈は腎静脈へ合流していた。写真上が頭側。
いか確かめながら慎重に剥離作業を進めた。尿管、 左卵巣静脈の走行を確認しつつ、頭側へ展開し、 左腎静脈下縁までリンパ節を摘出した。左側下大 静脈は左腎静脈に合流しているのが確認できた (写真 3 )。次に下大静脈 (以下IVC) と大動脈間 のリンパ節を摘出した。

その後術者は(1)に、カメラを正中 $12 \mathrm{~mm}$ ポート から患者足側へ向く方向に配置を変えた。

先ほど切断したB2下半分から、左総腸骨節を 摘出した (写真 4$)$ 。この部位も左側下大静脈か ら続く左総腸骨静脈の周囲に異常血管がある可能 性を念頭に置き慎重に操作を進めたが、一部その 周囲からの出血があり、止血操作を必要とした。

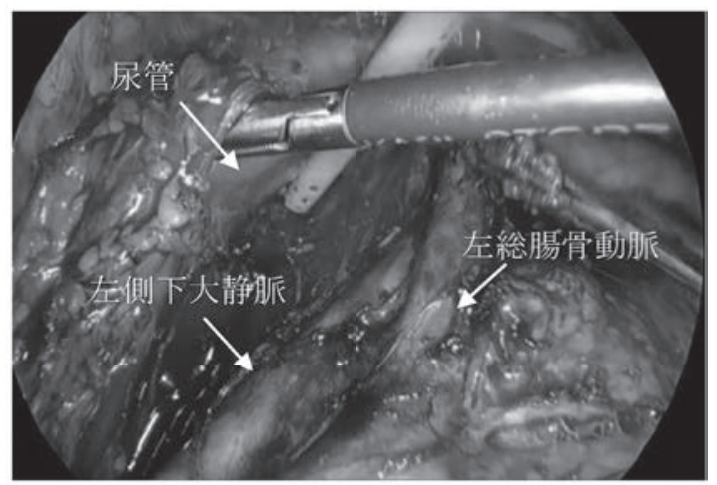

写真 4 左総腸節切除後。写真右上が尾側。
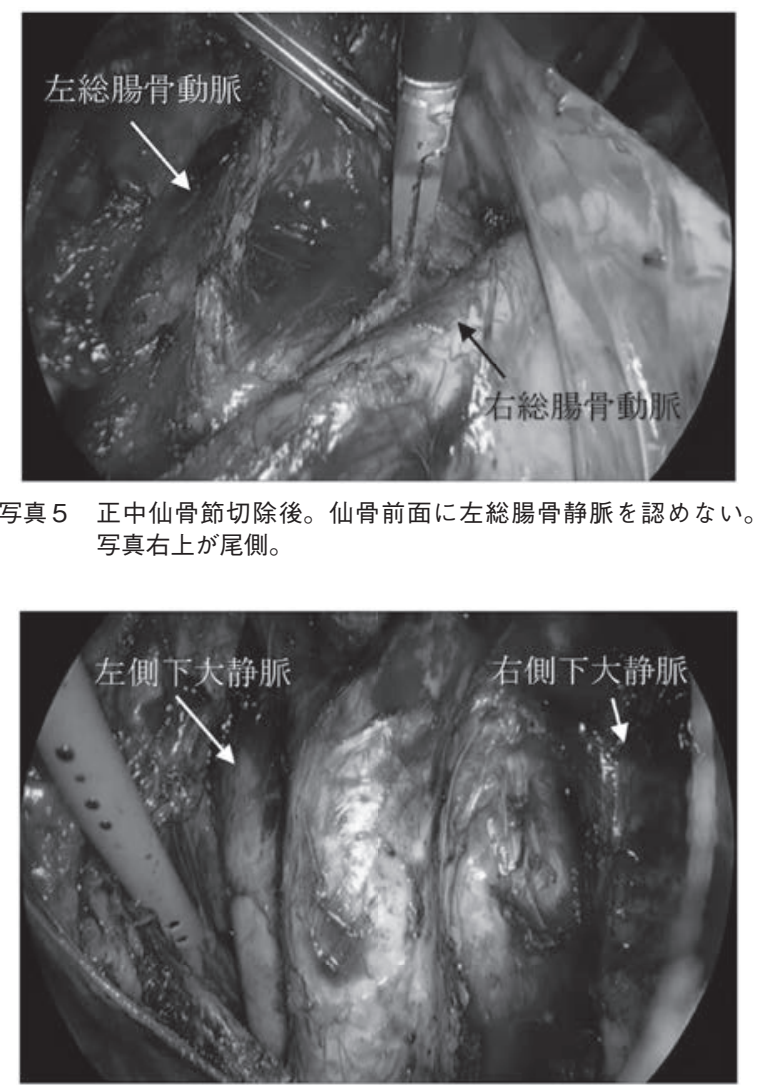

写真 6 PAN手術終了後。写真上が尾側。 
この出血は左下大静脈に流入するFellow's veinか らの出血が疑われた ${ }^{2)}$ 。続いて正中仙骨節を摘出 した。仙骨前面において、左右の下大静脈の合流 は見られず、それぞれ総腸骨静脈へ移行していた (写真 5$)$ 。

右総腸骨節を摘出し、止血確認を行った（写真 $6)$ 。摘出後、インフォメーションドレーンを扱 入し、手術終了となった。

本症例では手術時間 7 時間 40 分、出血量 $104 \mathrm{ml}$ 、 後腹膜リンパ節47個（骨盤リンパ節32個、傍大動 脈リンパ節15個）を摘出した。術翌日より食事、 歩行を開始した。術後経過良好にて術後4日目に 退院となった。病理組織診断にて stage I C1と判 断した。術後化学療法としてTC療法6コース施行 し、初回治療終了となった。現在再発所見なく 4 か月経過している。

\section{症 例 (2)}

40歳、 1 妊 0 産。近医にて左卵巣腫瘍を指摘さ れ、精查加療目的に当院紹介となった。術前MRI 検査にて卵巣癌を疑い、腹式左付属器切除術を行 った。術前に、病理結果によっては妊孕性温存手 術が許容できる報告があることを患者および家族 に説明を行ったが、患者とその家族は挙児希望は なく、境界悪性以上の病変であれば根治性を優先 することを強く希望した。術中迅速病理検査にて 境界悪性以上の腫瘍を認めたため、右付属器切除 術および子宮全摘術、大網切除術を追加施行した。 永久病理標本にて左卵巣明細胞癌であり、他切除 標本に病変を認めなかった。症例 1 と同様に本人 説明を行い、staging目的に腹腔鏡下骨盤リンパ 節及び傍大動脈リンパ節切除を予定した。術前 3D-CT検査（図 3 ）では、左側下大静脈を認め、 左右の下大静脈下端部を繋ぐ静脈、いわゆる腸骨 間静脈が確認できた。症例 1 と同様のポート配置 とし骨盤リンパ節切除の後、PAN手術を行った。 IMA根部の露出の段階で左下大静脈を同定した。 全体を通して症例 1 と同様の操作にて手術実施可 能であったが、仙骨前面に腸骨間静脈を認めた。 腸骨間静脈周囲にanomaly血管がないか確認しな がら正中仙骨節切除を行ったが特記すべき問題は なかった。一方で症例 1 と同じ部位にFellow's veinからと思われる出血を来し、止血操作を必要 とした。手術時間 6 時間26分、出血量 $201 \mathrm{ml}$ 、後 腹膜リンパ節46個（骨盤リンパ節32個、傍大動脈 リンパ節14個）を摘出した。術後経過に問題は認 めなかった。明細胞癌、stage I Aの診断にてTC

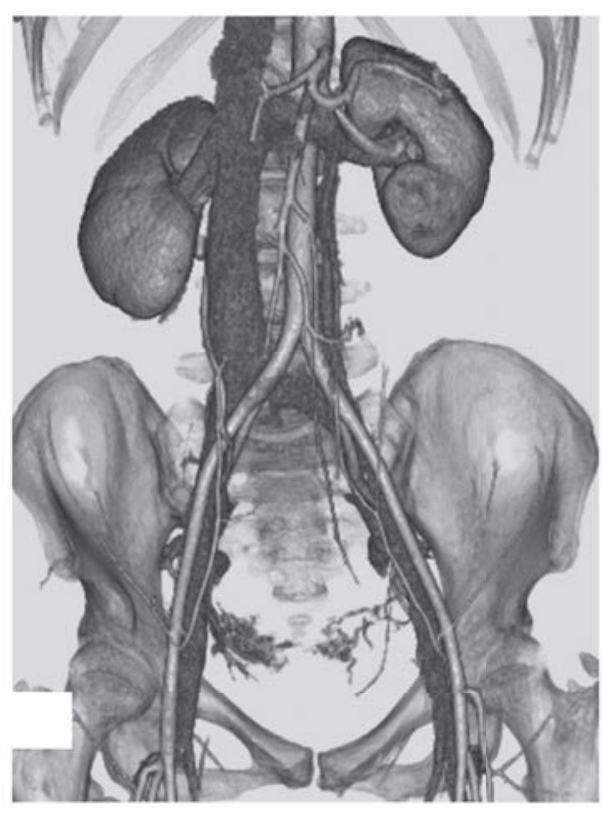

図 3 症例 2 3D-CT画像。重複下大静脈。左右の 下大静脈下端部を繋ぐ静脈、いわゆる腸骨間静 脈を認める。

療法を 6 コース施行し、現在再発所見なく 2 か月 経過している。

\section{考察}

重複下大静脈は0.3-2.2\%の頻度で認められる下 大静脈anomalyである ${ }^{3)}$ 。このanomalyそのもの は無症状であり、臨床的意義は少ない。胎生期の 発生過程において、下大静脈は 3 つの静脈系（主 上静脈、後主静脈、主下静脈）が統合または消失 し形成される ${ }^{4)}$ 。重複下大静脈は左右の主上静脈 が残存した場合に起こるとされる ${ }^{5)}$ 。下大静脈 anomalyは形成の仕方で様々なバリエーションを 持ち、Moritaらは総腸骨静脈との関係により図 4

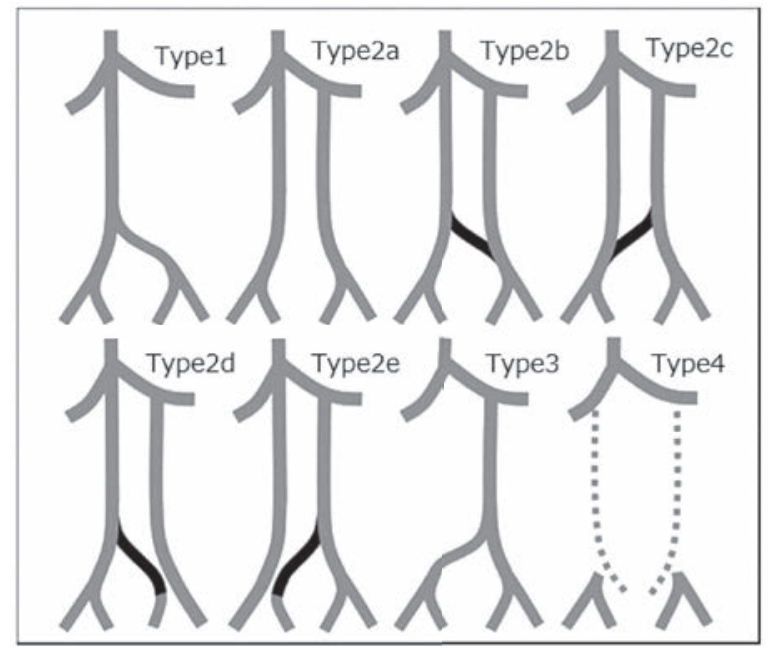

図 4 Pelvic venous variations of IVC anomalies 
のように下大静脈anomalyを分類している ${ }^{6)}$ 。こ の分類では症例 1 がtype2a、症例2がtype2bにそ れぞれ当てはまる。3つの静脈系の形成は腎血管 および性腺血管の形成にも関与するため、 anomaly complexやanatomic variationが付随し て起こる可能性があるとされる。そのため下大静 脈anomalyは発生異常が起こる部位により、下大 静脈後尿管、左側下大静脈、環状左腎静脈、 retroaortic renal vein、複数の腎静脈などの形成 に至るとされ、重複することもある ${ }^{4,7)}$ 。腎血管・ 尿管のanomalyはその処理の方法によっては術後 に部分的腎梗塞・水腎症などを招く危険性があり 注意が必要である ${ }^{8)}$ 。今回の 2 例に関しては、他 のanomalyの合併は認められなかった。

またBenedetti-Paniciらは、子宮頸癌、子宮体癌、 卵巣癌の治療のため開腹による骨盤抢よび傍大動 脈リンパ節切除術を受けた患者の $13.6 \%$ に血管 anomalyを認めたと報告している は稀とは言えず、腹部手術に際して問題となるこ とがあるため、 anomalyの有無の認識は必要と思 われる。CTやMRI、特に3D-CT Angiographyや MR Angiographyが血管anomalyの同定に有用と される ${ }^{7,10)}$ 。

下大静脈anomaly症例の腹腔鏡下手術はこれま で主に泌尿器科領域で報告されており ${ }^{11,12)}$ 、検索 し得た限り婦人科での報告はない。泌尿器科領域 において、腎血管・下大静脈anomalyのある腎癌 に対する腹腔鏡下腎摘出術に関する報告がいくつ かある。腹腔鏡下腎摘出術のアプローチ法には経
腹膜アプローチ法と後腹膜アプローチ法がある。 下大静脈anomaly症例では術中のオリエンテーシ ヨンを見誤る可能性が少ないとの理由で、経腹膜 アプローチ法を選択したという報告が散見され る。しかし症例によっては後腹膜アプローチ法が 可能であるとの報告もある ${ }^{11,13)}$ 。

PAN手術の術野展開も、後腹膜アプローチ法 と経腹膜アプローチ法、または併用する方法があ り、症例や施設によって選択される。それぞれの アプローチ法について文献的に指摘されている特 徵を表にした (表 1$)^{14-18)}$ 。経腹膜アプローチ法 では骨盤高位が必要で、腸管の影響がデメリット だが、視野・操作腔が広く、開腹での視野とほぼ 同一であるため、オリエンテーションが付きやす く、開腹への移行もスムーズである ${ }^{14,15,18,19)}$ 。一方、 後腹膜アプローチ法は骨盤高位が不要で大血管背 側の視野が得やすいというメリットがある ${ }^{20)}$ 。し かし、大動脈の両側に下大静脈がある場合、視野 や鉗子操作が障害され、そのメリットは生かされ ない可能性もあると思われた。

当科では現在、後腹膜アプローチ法による PAN手術は行っておらず、本症例も経腹膜アプ ローチ法を行った。大動脈右側のリンパ節郭清は 通常と同様であった。左側下大静脈は大動脈左側 にほほ接する位置を走行していたため、同定は容 易であったが、IMA根部の剥離操作の際、左側 下大静脈が近接し、操作腔が制限され慎重さを要 した。

anomaly血管は正常よりも拡張した構造であっ

表 1 経腹膜アプローチ法と後腹膜アプローチ法の文献上での比較

\begin{tabular}{|c|c|c|}
\hline & 経腹膜アプローチ法 & 後腹膜アプローチ法 \\
\hline 体位 & $\begin{array}{l}\text { 骨盤高位 } \\
\text { :横隔膜挙上、気道内圧上昇、脳圧元進など } \\
\text { 合併症を危惧する }\end{array}$ & 仰臥位で可能 \\
\hline 視野 & $\begin{array}{l}\text { 臟側腹膜の切開が必要 } \\
\text { :術後癒着の可能性 } \\
\text { 腸管の影響がある:腸管損傷のリスクがある } \\
\text { 視野は広く開腹での視野とほぼ同一 } \\
\text { :オリエンテーションが付きや寸い }\end{array}$ & $\begin{array}{l}\text { 腸管に影響されない } \\
\text { 開腹術の視野と異なるため、オリエンテー } \\
\text { ションのつけ方に慣れが必要 } \\
\text { 大血管 (特に大動脈) 背側の視野が得やす } \\
\text { い }\end{array}$ \\
\hline 操作性 & $\begin{array}{l}\text { 操作腔が広い } \\
\text { 開腹への移行がスムーズ } \\
\text { 大血管両側の広い範囲の郭清が可能 } \\
\quad \text { (特に動静脈問) } \\
\text { 大血管背側の操作はやや困難 }\end{array}$ & $\begin{array}{l}\text { 術野展開に技術が必要 } \\
\text { 腹膜損傷時の処理には意見が分かれる }\end{array}$ \\
\hline
\end{tabular}


たり、蛇行していたりするため、出血しやすいと 言われる7)。今回の症例においても、左側下大静 脈から左総腸骨静脈の移行部周囲の処理の際、数 か所から出血が認められた。バイポーラーにて止 血は可能であったが、慎重な剥離操作によっても 不測の出血が起こり得る印象であった。手術全体 として左下大静脈が操作の大きな障害となること はなく、他のanomalyがないことを術中確認しな がら操作を行い、通常の経腹膜アプローチ法とほ ぼ同様に術式施行可能であった。また、いずれの 症例においても輸血を要するような大量出血や腸 管損傷を含め、特記すべき合併症はなかった。後 腹膜アプローチ法との比較において優劣を語るこ とはできないが、3D-CTにて大血管anomalyが判 明した場合、空間的位置認識がしやすく、操作腔 が得やすい経腹膜アプローチ法の選択ないしは後 腹膜アプローチ法との併用が有用である可能性が あると考えた。

血管anomalyは稀なものではなく、またバリエ ーションに富んでいる。術前検査にて血管 anomalyの有無と解剖学的な位置関係を十分に検 討し、症例に応じた手術計画を立てることが重要 と思われた。

\section{結語}

重複下大静脈症例に対して経腹膜アプローチ法 によるPAN手術を行った。大血管anomaly症例で は小さな血管anomalyを合併することが多く、位 置関係や解剖学的指標を理解しながら手術を進め ることが必須である。大血管anomaly症例におけ るPAN手術は経腹膜アプローチ法が有用である 可能性がある。

本論文の要旨は第18回東海産婦人科内視鏡手術 研究会 $(2017$ 年10月, 名古屋) に㧍いて発表した。

すべての著者は開示すべき利益相反はない。

\section{文献}

1) Petra K, et al: Vascular anomalies in the paraaortic region diagnosed by laparoscopy in patients with gynaecologic malignancies. Gynecol Oncol. 2005; 96: 278-282.

2) 田畑務: 子宮体癌・卵巣癌に招けるStaging Laparotomy-en bloc骨盤・傍大動脈リンパ節郭清術、 2014;88

3) John M, et al: Anomalies of the Inferior Vena Cava.
Am Rentgen Ray Soc. 1983; 140: 339-345.

4) Timothy K. Byler, et al: Vascular anomalies during laparoscopic renal surgery: incidence and management of left-sided inferior vena cava. J Soc Laparo Surg. 2009; 13(1): 77-79.

5 ) 揖斐孝之、稲毛道憲、浅川光夫:重複下大静脈の1例、 日医大誌、2005; 1: 185-188.

6 ) Morita S, et al:Pelvic venous variations in patients with congenital inferior vena cava anomalies. Acta Radiol. 2007; 48: 974-979.

7 ) Ranjiv M, et al: Anomalies of the inferior vena cava and renal veins: Embryologic and surgical considerations. Urology. 1999; 53: 873-880.

8 ）佐藤洋一: 傍大動脈リンパ節郭清術のコッ、産婦の実 際、1997、46: 721-729.

9) Benedetti-Panici P, et al: Anatomic abnormalities of the retroperitoneum encountered during aortic and pelvic lymphadenectomy. Am J Obstet Gynecol. 1994; 170(1): 111-116.

10) Aneesh S, et al: Inferior vena cava in Urology: Importance of developmental abnormalities in clinical practice. Sci World J. 2005; 5: 558-563.

11）久保田恵章 他: 左側下大静脈に伴った右腎癌に対す る腹䏶鏡下根治的腎摘除の1例、泌尿紀要、2009、 55(7): 413-415.

12) Lin Hui Wang, et al: Left transperitoneal laparoscopic partial nephrectomy in the presence of a left-sided inferior vena cava. Urology. 2011; 78(2): 469-473.

13) Tomonori H, et al: Laparoscopic nephrectomy in patients with renal vein and/or inferior vena cava anomalies. Int J Urol. 2009; 16:854.

14）伊藤哲之: 腹膜到達法によるリンパ節郭清、腎移植 血管外科、2008、20:128-132.

15）原林徹、永森聡: 後腹膜リンパ節郭清術、泌尿、 2012、66(9): 653-657.

16）安藤正明 他: 内視鏡下腹膜外傍大動脈リンパ節郭清 術-両側側方アプローチ、日産婦内視鏡学会、2000、 16(2): $62-68$.

17）安部崇重 他: 腹腔鏡による腎孟尿管腫瘍手術の成績 と課題（特にリンパ節郭清）、Jpn J Endourol、 2016、29: 74-79.

18）光部兼六郎 他: 当科における経腹膜的アプローチに よる後腹膜リンパ節郭清術、産婦治療、2007、95(4): $-431-434$.

19）山下剛, 西岡嘉宏, 根岸秀明: 経腹膜的腹䏶鏡下傍大 動脈リンパ節摘出術の実際、日産婦内視鏡学会、 2012、28(2): 608-615.

20）安藤正明 他: 婦人科腹胺鏡下手術の実際、産婦治療、 2004、89(4) : 455-463

投稿日：2018年 7 月 17 日 採択日：2018年12月11日 